\title{
Vulvar Cancer pT1b TNM Finding v8
}

National Cancer Institute

\section{Source}

National Cancer Institute. Vulvar Cancer pT 1b TNM Finding v8. NCI Thesaurus. Code

C139603.

Vulvar cancer with lesion measuring more than $2 \mathrm{~cm}$, or any size with stromal invasion of more than $1.0 \mathrm{~mm}$, confined to the vulva and/or perineum. (from AJCC 8th Ed.) 